\title{
Limit rocznej podstawy wymiaru składek na ubezpieczenie emerytalne i rentowe - na marginesie wyroku Trybunału Konstytucyjnego sygn. K 1/18
} The limit of the annual contribution calculation basis to old-age and
disability insurance - in connection with the judgment of the
Constitutional Tribunal, reference number K $1 / 18$ dr Marcin Krajewski

Uniwersytet Łódzki, Wydział Prawa i Administracji, Katedra Prawa Pracy ORCID: 0000-0002-8869-0362 e-mail: marcin.krajewski@wpia.uni.lodz.pl

\begin{abstract}
Streszczenie Celem artykułu jest ukazanie wad i zalet likwidacji limitu rocznej podstawy wymiaru składek na ubezpieczenie emerytalne i rentowe. Ustawą z 15 grudnia 2018 r. znowelizowano art. 19 ust. 1 ustawy z 13 października 1998 r. o systemie ubezpieczeń społecznych. Zasadniczym celem nowelizacji przepisów była potrzeba obniżenia deficytu w Funduszu Ubezpieczeń Społecznych. Ustawa wprowadzała wyższe obciążenia z tytułu ubezpieczenia emerytalnego i rentowego najlepiej zarabiających pracowników. Przyjęte przepisy wymusiłyby działania optymalizacyjne po stronie płatników składek. W konkluzji autor krytykuje założenia nowelizacji ustawy.
\end{abstract}

Słowa kluczowe: ubezpieczenie emerytalne, ubezpieczenie rentowe, składka na ubezpieczenia społeczne, tytuł ubezpieczenia.

Summary The purpose of this paper is to present advantages and disadvantages of liquidation of the limit of the annual contribution calculation basis to old-age and disability insurance. The Act of December 15, 2018 amended art. 19 para. 1 of the Act of 13 October 1998 on the Social Insurance System. The main aim of the amendment to the Act was to decrease of State budget subsidy to cover the deficit in the Social Insurance Fund. The regulations introduced higher old-age and disability contributions for the best-earning employees. This will result in optimization activities on the payers' side. In conclusion the author criticizes the amendments to the Act.

Keywords: old-age insurance, disability insurance, social insurance contribution, insurance title.

JEL: K31

Str. $36-40$

\section{Bibliografia}

Bartnicki, M. (2014). Komentarz do art. 15 ustawy. W: K. Antonów (red.), Emerytury i renty z FUS. Emerytury pomostowe. Okresowe emerytury kapitałowe. Warszawa: Lex a Wolters Kluwer business.

Bińczycka-Majewska, T. (2000). Zbieg tytułów ubezpieczenia emerytalnego i rentowego w nowym systemie ubezpieczeń społecznych. Praca i Zabezpieczenie Społeczne, (12).

Bińczycka-Majewska, T. (2007). Kumulacja i rozłączność tytułów ubezpieczenia społecznego. Praca i Zabezpieczenie Społeczne, (1).

Jędrasik-Jankowska, I. (2003). Ubezpieczenie społeczne. Tom 1. Częśś ogólna. Warszawa: PWN.

Krajewski, M. (2018). Obciążenia dochodów podatkiem dochodowym i składkami na ubezpieczenia społeczne i zdrowotne — w kierunku jednej daniny czy pozostawienia obecnego modelu. Studia BAS, (2). 
Uziak, W. (2009). Podstawa wymiaru składek. W: A. Wypych-Żywicka (red.), Leksykon prawa ubezpieczeń społecznych. 100 podstawowych pojęć. Warszawa: C.H. Beck.

Wantoch-Rekowski, J. (2005). Składki na ubezpieczenia emerytalne. Konstrukcja i charakter prawny. Toruń: Dom Organizatora.

Wilczyński, M. (2011). Komentarz do art. 19 ustawy. W: B. Gudowska, J. Strusińska-Żukowska (red.), Ustawa o systemie ubezpieczeń społecznych. Komentarz. Warszawa: C.H. Beck.

Zarzycki, M. (2017). Bezwarunkowy dochód podstawowy — przyszłość prawa pracy i ubezpieczeń społecznych czy utopia? Praca $i$ Zabezpieczenie Społeczne, (6). 